\title{
Natural hybridization between genetically differentiated populations of Crassostrea gigas and $C$. angulata highlighted by sequence variation in flanking regions of a microsatellite locus
}

\author{
A. Huvet ${ }^{1,2}$, C. Fabioux ${ }^{1,2}$, H. McCombie ${ }^{1}$, S. Lapègue ${ }^{1}$, P. Boudry ${ }^{1, *}$ \\ ${ }^{1}$ Laboratoire de Génétique et Pathologie, IFREMER, 17390 La Tremblade, France \\ ${ }^{2}$ Present address: Laboratoire de Physiologie des Invertébrés, IFREMER, Centre de Brest, BP 70, 29280 Plouzané, France
}

\begin{abstract}
The marine environment is of special interest for studying hybridization between closely related taxa because of the high dispersal potential of planktonic larvae, such as those of most bivalve species. The oysters Crassostrea angulata and C. gigas are known to be very close genetically and entirely inter-fertile under controlled conditions. However, hybridization in the wild had not been investigated, mainly due to the lack of nuclear diagnostic markers. In the present paper, we first estimated genetic differentiation between these 2 closely related taxa using 8 microsatellite markers. Interestingly, 5 markers displayed significant differences of allele size between taxa. The subsequent sequencing of alleles of one of these microsatellites showed several mutational events, which suggested null alleles and homoplasy. The presence of 1 insertion/deletion event in its 5 ' flanking sequence enabled us to design a new bi-allelic (' $\mathrm{C}$ ' and ' $\mathrm{NC}$ ') nuclear PCR-restriction fragment length polymorphism (-RFLP) marker (CG44R). This, together with a mitochondrial DNA marker, was used to analyze populations of $C$. angulata and $C$. gigas. The CG44R allele frequencies were very different between $C$. angulata $(f[C]=0.91)$ and $C$. gigas $(f[N C]=0.92)$ populations. This analysis also provided evidence for hybridization between C. angulata and C. gigas in a wild Portuguese population where the 2 taxa are in contact due to recent transportation of $C$. gigas stocks for aquacultural production. Our results represent the first indication of hybridization between these 2 taxa in the natural environment, and contribute to knowledge of the evolutionary history of the Crassostrea genus.
\end{abstract}

KEY WORDS: Crassostrea angulata · Crassostrea gigas · Hybridization · Genetic differentiation · Microsatellites · Allele size

\section{INTRODUCTION}

Natural hybridization consists of successful mating between individuals from populations which are otherwise distinguishable by 1 or more heritable characters (Arnold 1997). The spatial and temporal overlap of populations or their gametes, allowing hybridization to occur, is commonly known as a 'hybrid zone'. The marine environment is of special interest in the study of such processes because both individuals and gametes are thought to disperse over large distances
(Hedgecock 1986, 1994, Palumbi \& Wilson 1990, Bohonak 1999, but see Taylor \& Hellberg 2003). In marine bivalves, several hybrid zones are well documented in clams (Mercenaria spp.: Bert et al. 1993) and mussels (Mytilus spp. complex: Koehn 1991, Inoue et al. 1997, Rawson et al. 1999, Bierne et al. 2002). In the Baltic mussel hybrid zone, asymmetric introgression and natural selection were suggested to explain discordance between allozyme and non-allozyme patterns (Riginos et al. 2002). In oysters, despite much experimental evidence of inter-specific crosses in the 
genus Crassostrea (see for review Gaffney \& Allen 1993), natural hybridization between species has never been reported in the wild (Hedgecock et al. 1999).

In the genus Crassostrea, C. gigas and C. angulata were first classified as 2 different species by Thunberg in 1793 and Lamark in 1819, respectively. This classification was chiefly due to their apparently separated geographical distribution. C. angulata was described in Europe and C. gigas in Asia. However, following morphological comparison (Ranson 1948), experimental hybridization (reviewed by Gaffney \& Allen 1993, Huvet et al. 2001, 2002) and allozyme data (Mathers et al. 1974, Buroker et al. 1979, Mattiucci \& Villani 1983), the authors concluded that there was only a single species grouping Portuguese and Pacific oysters. However, significant phenotypic differences between the 2 taxa were observed. C. gigas shows a superior production yield in the natural environment in France (Bougrier et al. 1986, Héral 1986, Parache 1989, Soletchnick et al. 2002), as its growth is twice that of the Portuguese oyster (Bougrier et al. 1986). Differences were also shown in terms of their ecophysiological characteristics (His 1972, Goulletquer et al. 1999, Haure et al. 2003). Furthermore, genetic differences have now been observed on several levels. Karyotype analyses highlighted the close genetic similarity of these 2 taxa in comparison with other cupped oyster species (Leitão et al. 1999a), although differences between C. angulata and C. gigas were observed, notably for Chromosome 7 (Leitão et al. 1999b). Two studies on the mitochondrial Cytochrome Oxidase Subunit I (COI) gene (Boudry et al. 1998, O'Foighil et al. 1998) demonstrated a clear genetic difference (nucleotide divergence of $5.26 \%$ ) between the 2 taxa. Finally, a recent microsatellite analysis of cupped oyster populations of C. gigas and C. angulata revealed a low but significant genetic differentiation between populations of the different taxa (mean Wright's fixation index; $F_{\text {st }}=0.022$; Huvet et al. 2000b). This differentiation was twice as large as the genetic differentiation estimated between geographically separated populations of the same taxon (Mean $F_{\text {st }}=0.01$; Huvet et al. 2000b). These last 3 studies also offered an explanation for the separated geographical distribution of the taxa by supporting the hypothesis of the introduction of C. angulata from Asia (and more precisely Taiwan) to the Portuguese coast by merchant ships during the 16th century. For C. gigas, voluntary introduction from Japan into Europe was made in the early 1970s to replace C. angulata in the shellfish industry (Grizel \& Héral 1991) because of an iridoviral infection (Comps 1969) which wiped out C. angulata from French coasts between 1967 and 1972. Based on these analyses, there might be 2 putative contact zones, 1 between France and the south of Portugal, where 'naturalized'
C. gigas and $C$. angulata populations have been described, and a second between Japan and Taiwan. However, despite the absence of reproductive barriers under controlled conditions (Huvet et al. 2001, 2002), natural hybridization in these contact zones remain to be investigated. In the mitochondrial (mt) DNA study (Boudry et al. 1998), a diagnostic mtDNA marker was identified at the population level but is unsuited to the study of hybrids and hybridization processes because of its haploid nature and maternal transmission (Boursot \& Bonhomme 1986). A nuclear diagnostic marker that would easily distinguish the taxa and their hybrids was therefore needed to study this phenomenon.

In the present paper, we report the analysis of 8 microsatellite loci on samples of the 2 closely related taxa, C. gigas and C. angulata, leading to the design of a new nuclear PCR-restriction fragment length polymorphism (-RFLP) marker in the 5'-flanking sequence of one of these microsatellites. This nuclear marker allowed us to study hybridization between $C$. angulata and $C$. gigas in the wild along the Atlantic European coast. The genetic differentiation between wild populations of both taxa, estimated with a mitochondrial marker as opposed to a nuclear marker, is compared and discussed in terms of evolutionary history of the 2 cupped oyster taxa.

\section{MATERIALS AND METHODS}

Biological material. Fifteen populations of cupped oysters were collected from a large area along the European Atlantic and Asian Pacific coasts (Table 1). In total, 12 European populations and 3 Asian populations (corresponding to 653 individuals) were sampled, of which 9 (Oga, Seu, Arc, Bou, Mir, Rfa, Cad, Kee and Kao; see Table 1 for abbreviations) had been previously identified as Crassostrea gigas (Japan, France) or C. angulata (Taiwan, South of Spain and Portugal) using a mitochondrial marker (Boudry et al. 1998, Huvet et al. 2000b). Samples of mantle or gills were preserved in $95 \%$ ethanol. DNA extraction was performed by the phenol/chloroform method as described in Moore (1993).

Microsatellite analysis. In total, 8 dinucleotide microsatellite loci (CG44, CG49, CG108, L8, L10, L16, L48 and $\mu$ satAMY) were analyzed in 186 individuals (93 per taxa) sampled from 3 C. gigas (Oga, Seu, Arc) and 4 Crassostrea angulata (Mir, Cad, Kee, Kao) populations (Table 1), as previously determined based on a mtDNA marker (Huvet et al. 2000b). The last 2 previously studied populations (Bou and Rfa) were not considered at this step because they presented haplotypes from both taxa. Three of the markers had previously been used to analyze these samples for genetic differ- 
entiation (CG44, CG49, CG108 in Huvet et al. 2000b). Primer sequences were available in Magoulas et al. (1998) for CG44, CG49, CG108, in Huvet et al. (2000a) for L8, L10, L16, L48 and in Sellos et al. (2003) for usatAMY locus. Radioactive PCR amplifications were carried out in a total volume of $10 \mu \mathrm{l}$ using $10 \mathrm{ng}$ of oyster genomic DNA. The concentrations of the reaction components were as follows: $1 \times$ Taq buffer, $0.2 \mathrm{mM}$ dNTPs, $0.14 \mu \mathrm{M}$ forward primer, $3 \mathrm{mM} \mathrm{MgCl}_{2}$ for CG44, $2 \mathrm{mM}$ for CG49, $1.5 \mathrm{mM}$ for L48 or $1 \mathrm{mM}$ for other loci, and $0.017 \mathrm{U}$ Taq polymerase. The reverse primer of each pair $(0.23 \mu \mathrm{M})$ was end-labelled with $1 \mu \mathrm{Ci} \gamma 33 \mathrm{P}, 1 \mathrm{X}$ kinase buffer and $0.6 \mathrm{U}$ kinase for $30 \mathrm{~min}$ at $37^{\circ} \mathrm{C}$. Amplification was performed using 30 cycles of 1 min denaturation at $94^{\circ} \mathrm{C}, 1$ min annealing at $53^{\circ} \mathrm{C}$ for CG44 and $\mathrm{CG} 49,55^{\circ} \mathrm{C}$ for CG108, L10 and usatAMY, $57^{\circ} \mathrm{C}$ for L8 and L16 or $60^{\circ} \mathrm{C}$ for L48, and 1 min extension at $72^{\circ} \mathrm{C}$. PCR products were separated on $6 \%$ denaturating polyacrylamide gels for 3 to $5 \mathrm{~h}$ at $50 \mathrm{~W}$ (voltage and intensity were set up to give nonlimiting conditions at $1900 \mathrm{~V}$ and $150 \mathrm{~mA}$, respectively). Gels were run, dried and exposed to film for 6 to $48 \mathrm{~h}$. Alleles were numbered according to their size (given in base pairs; bp).

Allele sequencing. After their separation on polyacrylamide gel, 2 different alleles of the CG44 locus were extracted from the gel, and re-amplified by PCR under the same conditions as described above (carried

Table 1. Crassostrea gigas and C. angulata. Location and sample size (N) of the 15 populations sampled in Europe and Asia. All samples were analyzed with the 2 PCR-restriction fragment length polymorphism (-RFLP) markers: the CG44R marker and the mitochondrial (mt)DNA Cytochrome Oxidase Subunit I (COI) marker. Number of individuals analyzed with the 8 microsatellite markers is given in parentheses (n)

\begin{tabular}{|c|c|c|c|}
\hline Origin (country) & $\begin{array}{l}\text { Abbre- } \\
\text { viation } \\
N(n)\end{array}$ & $\begin{array}{c}\text { Previously } \\
\text { determined } \\
\text { or presumed } \\
\text { taxa }\end{array}$ & $\mathrm{N}\left(\mathrm{n}^{\mathrm{a}}\right)$ \\
\hline Hiroshima (Japan) & Oga & C. gigas $^{\mathrm{a}}$ & $49(31)$ \\
\hline Seudre Estuary (France) & Seu & C. gigas $^{\mathrm{a}}$ & $49(31)$ \\
\hline Arcachon Bay (France) & Arc & C. gigas $^{\mathrm{a}}$ & $50(31)$ \\
\hline Vieux-Boucau Bay (France) & Bou & C. gigas $^{\mathrm{a}}$ & 49 \\
\hline Orio (Spain) & Ori & C. gigas & 50 \\
\hline Ribadesella (Spain) & Rib & C. gigas & 50 \\
\hline Vicedo, Rio del Barquero (Spain) & Vic & C. gigas & 50 \\
\hline Setubal (Portugal) & Set1 & C. angulata & 50 \\
\hline Rio Mira Estuary (Portugal) & Mir & C. angulata ${ }^{\mathrm{a}}$ & $30(24)$ \\
\hline Tavira (Portugal) & Tar & C. angulata & 50 \\
\hline Ria Formosa, Faro (Portugal) & Rfa & C. angulata ${ }^{\mathrm{a}}$ & 35 \\
\hline Guadalquivir, Sanlucar de Barrameda (Spain) & ) Gua & C. angulata & 50 \\
\hline Cadiz (Spain) & Cad & C. angulata ${ }^{\mathrm{a}}$ & $21(21)$ \\
\hline Tungkang (Taiwan) & Kee & C. angulata ${ }^{\mathrm{a}}$ & $30(20)$ \\
\hline Kaohsiung (Taiwan) & Kao & C. angulata ${ }^{\mathrm{a}}$ & $40(28)$ \\
\hline
\end{tabular}

out in a total volume of $50 \mu \mathrm{l})$. These single DNA fragments were cloned into the plasmidic vector pCR II (Invitrogen) and then manually sequenced using an oligonucleotide tailing kit (Boehringer-Mannheim) and $\gamma 33 \mathrm{P}$ radiolabeled dNTPs.

PCR-RFLP analysis. Twelve European and 3 Asian samples of Crassostrea angulata and C. gigas populations (corresponding to 653 individuals) were analyzed with 2 PCR-RFLP markers: a nuclear DNA marker and the mtDNA COI marker. For this mitochondrial marker, 9 populations had previously been analyzed (Boudry et al. 1998, Huvet et al. 2000b; Table 1).

Nuclear DNA RFLP. The CG44 microsatellite marker was amplified as described above and then digested using the $B s r G I$ endonuclease. The restriction reaction was performed for $2 \mathrm{~h}$ at $37^{\circ} \mathrm{C}$ in a $20 \mu \mathrm{l}$ volume composed of $10 \mu \mathrm{l}$ PCR product, $2 \mu \mathrm{l} 10 \times$ reaction buffer and $7 \mathrm{U}$ BsrGI enzyme. The digested samples were then separated by electrophoresis on $1 \%$ agarose gels in 1× TAE buffer (Tris-acetic acid-EDTA), followed by staining with ethidium bromide. Visualization was carried out under UV light and recorded on a computer linked to a video camera.

mtDNA RFLPs. A 710 bp segment of the COI mitochondrial gene was amplified by PCR as described in Boudry et al. (1998). As previously reported (Boudry et al. 1998, Huvet et al. 2000b), 4 endonucleases (TaqI, Sau3A, HhaI and MseI) were polymorphic and revealed 6 different haplotypes of which 4 appeared to be specific to Crassostrea angulata populations (Haplotypes A, B, D and J) and 2 to C. gigas (Haplotypes $\mathrm{C}$ and $\mathrm{E})$. Separation and visualization were achieved in the same manner as for the nuclear PCR-RFLP. The haplotype network is provided in Boudry et al. (1998), and a phylogenetic tree, based on DNA sequence data of these haplotypes, is presented in Boudry et al. (2003).

Data analysis. All the statistical analyses of size of microsatellite alleles were carried out by analysis of variance using SYSTAT 9.0 (Wilkinson 1990) under the general linear model procedure. Statistical comparison of the number of microsatellite alleles between taxa was made using a chisquare test.

Genetic differentiation was estimated between the Crassostrea gigas and $C$. angulata samples, each consisting of 93 individuals. Two estimators of genetic differentiation were obtained. Firstly, F-statistics, as described by 
Wright (1951), were calculated according to Weir \& Cockerham (1984) using the package GENETIX Version 4.01 for computations and tests (Belkhir et al. 1996-2001). Secondly, the $R_{\mathrm{st}}$ parameter (Slatkin 1995a), which takes into account allele size, was computed and tested using the $R_{\mathrm{ST}}$ Calculation package Version 2.1 (Goodman 1997). Unbiased estimates and SDs of heterozygosity at microsatellite loci and the CG44R locus were calculated according to the parameter $F_{\text {is }}$ (Wright's inbreeding coefficient). Deviations from Hardy-Weinberg expectations were tested in each sample by generating 50000 permutations. Sequential Bonferroni adjustment of the p-values (Rice 1989) was used to correct tests of $F_{\text {is }}$.

The nucleo-cytoplasmic linkage disequilibrium was estimated from the Linkdisk algorithm (Black \& Krafsur 1985). These computations and tests were done using the package GENETIX Version 4.01.

A test for deviation from selective neutrality was realized for the microsatellite data using Arlequin (Schneider et al. 2000) with the Chakraborty's test of population amalgamation procedure (Chakraborty 1990). This test compares the number of alleles in a sample with the number expected in a stationary population at mutation-drift equilibrium. It is based on the infinite allele mutation model.

\section{RESULTS}

\section{Microsatellite genotyping: allele size variation and population differentiation}

Individuals were genotyped $(\mathrm{n}=186,93$ for each taxon) at 5 microsatellite loci, which enlarged the existing data already produced with 3 other loci (Huvet et al. 2000b). The total number of alleles per locus was very high, ranging from 36 to 52 (mean number $=45$, Table 2). The number of alleles present in each taxon was not significantly different for any locus or over all loci ( $0.1 \%$ level). Over all loci, the mean allele size was not significantly different between Crassostrea gigas and C. angulata either. However, 2 loci, L8 and L48, showed a significantly higher mean allele size (4 bp difference) in $C$. gigas samples than in $C$. angulata samples (Table 2). Conversely, 3 other loci, CG44, CG49 and CG108, showed significantly higher mean allele size in $C$. angulata samples than in C. gigas samples (Table 2). The greatest difference in size, $21 \mathrm{bp}$, was noted at the CG44 locus.

From these 8 microsatellite loci, the genetic differentiation between the taxa was estimated with $F_{\mathrm{st}}$ and $R_{\mathrm{st}}$ parameters, which gave 0.022 for the $F_{\text {st }}$ estimate and 0.15 for the $R_{\mathrm{st}}$ estimate (12.5 times higher than $F_{\mathrm{st}}$ ). Both values were significantly different from 0 (at the $0.1 \%$ level). Hardy-Weinberg expected heterozygosity and observed heterozygosity ranged from 0.32 (L8, OGA population) to 1 (CG108, KEE population) and from 0.68 ( ssatAMY, Mir population) to 0.98 (L48, Kao population), respectively. Half of the $F_{\text {is }}$ values, ranging from -0.05 to 0.67 , were found to be significant after Bonferroni correction (27 values out of the 56 tested, Table 3) indicating significant heterozygote deficiencies. One locus, L16, showed significant heterozygote deficiencies in all populations. The $F_{\text {st }}$ estimate was re-estimated without this locus due to its consistent heterozygote deficiencies across all populations. The result was 0.024 instead of the 0.022 (described above).

The test for deviation from selective neutrality showed non-significant values ( $p>0.05$ ), apart from the microsatellite amylase ( $\mu$ satAMY) result in the Mir population, which appeared significant at the $5 \%$ level $(p=0.0476)$.

\section{Characterization of CG44R alleles in the 2 taxa}

Because the greatest difference in mean size, $21 \mathrm{bp}$, was at the CG44 locus (Table 2), we cloned and sequenced 2 CG44 alleles: a large allele (266 bp) from a

Table 2. Crassostrea gigas and C. angulata. Total allele number and allele number in each taxon, mean size of microsatellite alleles in each taxon (Tg in C. gigas and Ta in C. angulata) and ANOVA for the 8 microsatellite loci analyzed in 93 oysters of each taxon. ${ }^{*}$ p < 0.05 , ${ }^{* *} \mathrm{p}<0.01,{ }^{* * *} \mathrm{p}<0.001$

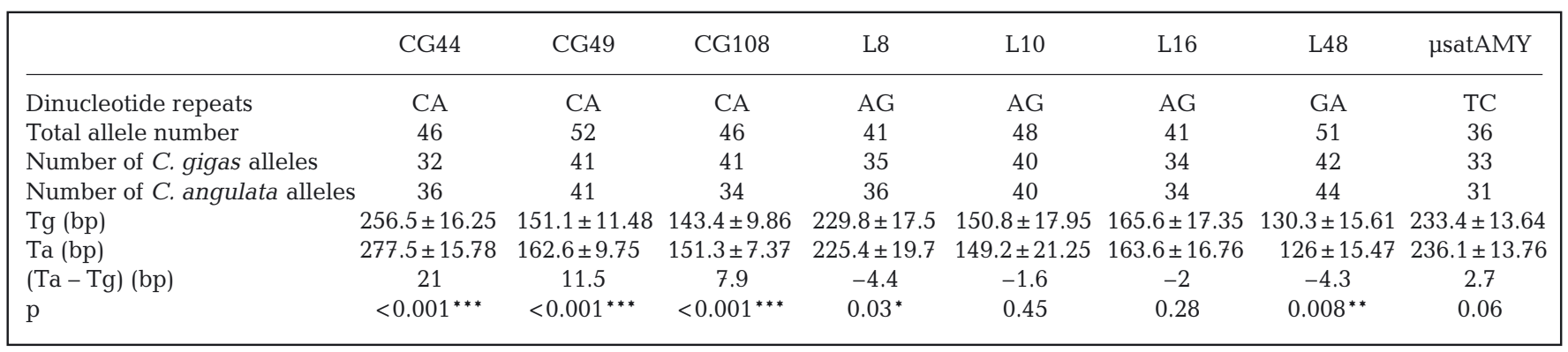


Table 3. Crassostrea gigas and $C$. angulata. Observed $\left(H_{\mathrm{o}}\right)$ and expected $\left(H_{\mathrm{e}}\right)$ heterozygosity and $F_{\text {is }}$ (Wright's inbreeding coefficient) values for each analyzed population and microsatellite locus. $F_{\text {is }}$ ( $F$-statistic of Wright 1951) was calculated according to Weir \& Cockerham (1984). The significance of the $F_{\text {is }}$ values was estimated by generated permutations (50 000) of individual genotypes within each population. ${ }^{*} \mathrm{p}<0.05$. Significant values after sequential Bonferroni adjustment at the $\mathrm{p}<0.05$ level are indicated in bold. See Table 1 for population abbreviations

\begin{tabular}{|c|c|c|c|c|c|c|c|c|}
\hline & & Oga & Seu & Arc & Mir & Cad & Kee & Као \\
\hline \multirow[t]{3}{*}{ CG44 } & $H_{\mathrm{o}}$ & 0.43 & 0.81 & 0.9 & 0.79 & 0.57 & 0.68 & 0.93 \\
\hline & $H_{\mathrm{e}}$ & 0.96 & 0.95 & 0.96 & 0.92 & 0.9 & 0.95 & 0.96 \\
\hline & $F_{\text {is }}$ & $0.56^{*}$ & $0.15^{*}$ & 0.05 & $0.15^{*}$ & $0.37^{*}$ & $0.29^{*}$ & 0.03 \\
\hline \multirow[t]{3}{*}{ CG49 } & $H_{\mathrm{o}}$ & 0.97 & 0.62 & 0.81 & 0.92 & 0.9 & 0.63 & 0.7 \\
\hline & $H_{\mathrm{e}}$ & 0.97 & 0.97 & 0.95 & 0.91 & 0.96 & 0.95 & 0.96 \\
\hline & $F_{\text {is }}$ & 0.004 & $0.36^{*}$ & $0.15^{*}$ & -0.01 & 0.063 & $0.34^{*}$ & $0.27^{*}$ \\
\hline \multirow[t]{3}{*}{ CG108 } & $H_{\mathrm{o}}$ & 0.87 & 0.74 & 0.9 & 0.82 & 0.76 & 1 & 0.89 \\
\hline & $H_{\mathrm{e}}$ & 0.96 & 0.97 & 0.96 & 0.96 & 0.95 & 0.96 & 0.96 \\
\hline & $F_{\text {is }}$ & $0.1^{*}$ & $0.24^{*}$ & 0.06 & $0.14^{*}$ & $0.2^{*}$ & -0.05 & $0.07^{*}$ \\
\hline \multirow[t]{3}{*}{ L8 } & $H_{0}$ & 0.32 & 0.43 & 0.71 & 0.71 & 0.6 & 0.5 & 0.5 \\
\hline & $H_{\mathrm{e}}$ & 0.95 & 0.95 & 0.93 & 0.96 & 0.86 & 0.92 & 0.88 \\
\hline & $F_{\text {is }}$ & $0.67^{*}$ & $0.54^{*}$ & $0.23^{*}$ & $0.26^{*}$ & $0.31^{*}$ & $0.46^{*}$ & $0.44^{*}$ \\
\hline \multirow[t]{3}{*}{ L10 } & $H_{\mathrm{o}}$ & 0.68 & 0.9 & 0.97 & 0.71 & 0.85 & 0.89 & 0.93 \\
\hline & $H_{\mathrm{e}}$ & 0.96 & 0.97 & 0.96 & 0.95 & 0.97 & 0.97 & 0.97 \\
\hline & $F_{\text {is }}$ & $0.3^{*}$ & 0.07 & -0.007 & $0.25^{*}$ & $0.13^{*}$ & $0.08^{*}$ & $0.05^{*}$ \\
\hline \multirow[t]{3}{*}{ L16 } & $H_{0}$ & 0.63 & 0.68 & 0.63 & 0.54 & 0.8 & 0.7 & 0.52 \\
\hline & $H_{\mathrm{e}}$ & 0.95 & 0.96 & 0.96 & 0.95 & 0.96 & 0.94 & 0.96 \\
\hline & $F_{\text {is }}$ & $0.35^{*}$ & $0.3^{*}$ & $0.34^{*}$ & $0.43^{*}$ & $0.17^{*}$ & $0.27^{*}$ & $0.45^{*}$ \\
\hline \multirow[t]{3}{*}{ L48 } & $H_{\mathrm{o}}$ & 0.87 & 0.87 & 0.84 & 0.96 & 0.57 & 0.85 & 0.79 \\
\hline & $H_{\mathrm{e}}$ & 0.96 & 0.97 & 0.97 & 0.92 & 0.94 & 0.96 & 0.98 \\
\hline & $F_{\text {is }}$ & $0.1^{*}$ & $0.11^{*}$ & $0.14^{*}$ & -0.05 & $0.39^{*}$ & $0.11^{*}$ & $0.2^{*}$ \\
\hline \multirow[t]{3}{*}{ psatAMY } & $H_{\mathrm{o}}$ & 0.84 & 0.87 & 0.71 & 0.58 & 0.82 & 0.95 & 0.81 \\
\hline & $H_{\mathrm{e}}$ & 0.96 & 0.97 & 0.94 & 0.68 & 0.93 & 0.95 & 0.94 \\
\hline & $F_{i s}$ & $0.13^{*}$ & $0.1^{*}$ & $0.25^{*}$ & $0.14^{*}$ & $0.13^{*}$ & 0.003 & $0.13^{*}$ \\
\hline
\end{tabular}
GTGAATTTAACTTCCTGCGTTAAGGAAGCTGGATGATCAACAAATTAACCGTCAGATATAC 1111111111111111111111111111111111111111111111111111111111111

1 GTGAATTTAACTTCCTGTGTTAAGGAAGCTGGATGATCAACAAATCAACCGTCAGATATAC

62

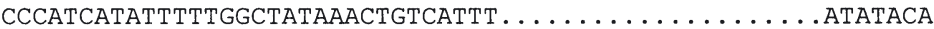
11111111111111111111111111111111 111111

62 CCCATCATATTTTTGGCTATAAACTGTCATTTGGTAAAGCCAAATATGTGTACATGTACA

101

122

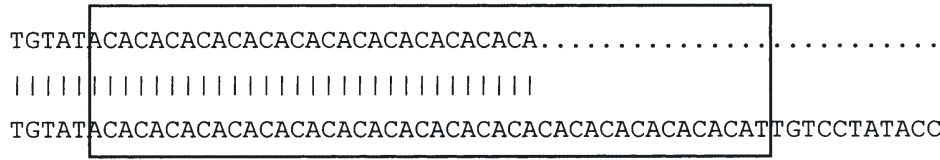
$\ldots \ldots \ldots \ldots \ldots \ldots \ldots \ldots \ldots \ldots$ CTGTCCTTCCATTACTCTATAAACAACGT AGACATCTTTATCAAACGAACTATACAACATCTCTATACAAATTACTCTATAAACAACAT

164

242

\section{GTCTGTTAGTCAATTATGATAAAAA}

111111111111111111111111111 GTCTGTTAGTCAATTATGATAAAAA

Fig. 1. Crassostrea gigas and C. angulata. Alignment of 2 CG44 microsatellite allele sequences (above: 188 bp allele from a C. gigas individual; below: $266 \mathrm{bp}$ allele from a $C$. angulata individual). The dinucleotide repeat is framed and the $21 \mathrm{bp}$ insertion is underlined. The restriction site of BsrGI in the first insertion is in bold
Crassostrea angulata individual and a small one (188 bp) from a C. gigas individual. The sequences of both alleles (GenBank Accession Nos. AF527994 and AF527995) are presented in Fig. 1. Their alignment revealed 11 substitutions, 2 insertions (of 21 and $43 \mathrm{bp}$ ), located in both parts of the microsatellite repeat, and a difference of 7 repeated elements (CA). These 2 insertions and the 7 additional repeated elements were present in the large $266 \mathrm{bp} C$. angulata allele, explaining the $78 \mathrm{bp}$ difference between the alleles sequenced. It was not possible to examine the presence/absence of the 43 bp insertion by RFLP because no restriction site was observed, or by specific PCR amplification because of the appreciable redundancy of some interrupted motifs in the 3'-flanking region. However, because the $21 \mathrm{bp}$ insertion contained a BsrGI restriction site, it was possible to seek this insertion by a PCR-RFLP method (PCR amplification with the CG44 primers and 


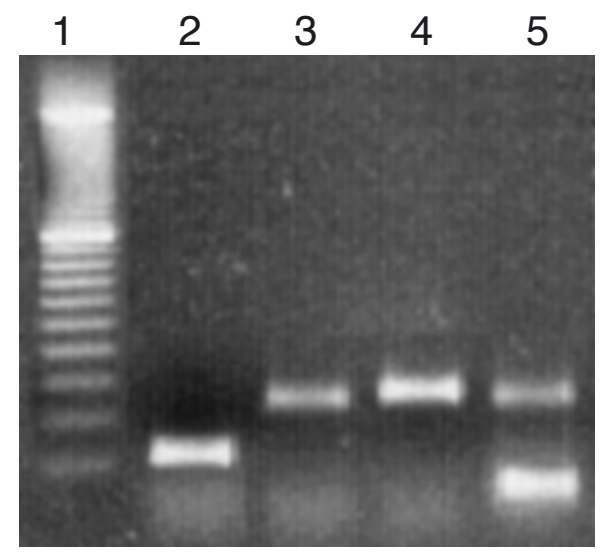

Fig. 2. Crassostrea gigas and C. angulata. Electrophoresis of digestion products of the CG44R marker from a set of $C$. gigas and C. angulata. Lane 1: $1 \mathrm{~kb}$ ladder; Lanes 2 to 5: Kao 25 (C/C); Oga 34 (NC/NC); Oga 35 (NC/NC), Tar 50 (C/NC) (see Table 1 for population abbreviations). Genotypes are given between brackets; $\mathrm{C}$ and NC correspond to the cut and noncut alleles, respectively

digestion with the BsrGI endonuclease). The results (obtained on the same 2 sets of 93 oysters per taxon) showed a high frequency of this $21 \mathrm{bp}$ insertion (represented by the cut [C] allele) in the C. angulata sample $(91 \%)$, whereas in the C. gigas sample its frequency did not exceed $8 \%$ (92\% of the non-cut [NC] allele) (Fig. 2). This newly designed marker for analyzing the presence/absence of the $21 \mathrm{bp}$ insertion in the CG44 microsatellite flanking region by restriction with $B s r G I$ was named CG44R. It provided a suitable new tool for the study of hybridization between the 2 taxa.

\section{Hybridization in European populations}

Hardy-Weinberg expected heterozygosity at the CG44R locus (Table 4) ranged from 0.032 (Orio) to 0.344 (Tavira). The mean observed heterozygosity, $H_{0}$ was equal to 0.149 over all the populations, ranging from 0 (Ribadesella) to 0.304 (Tavira). $F_{\text {is }}$ values (departure from Hardy-Weinberg equilibrium) ranged from -0.13 (Kaohsiung) to 1 (Ribadesella) with a mean value over all populations equal to 0.21 . Five values of $F_{\text {is }}$ out of the 15 tested were found to be significant after Bonferroni correction (Table 4), indicating heterozygote deficiencies in Hiroshima, Seudre, Ribedesella, Ria Formosa and Tungkang populations. The mean $F_{\text {st }}$ value between pairs of populations of different taxa was 0.71 for the CG44R locus.

Following the results of Boudry et al. (1998) and Huvet et al. (2000b), who observed haplotypes of the COI marker specific to Crassostrea gigas and C. angulata populations, the 2 main haplotype clusters are reported with their allele frequencies in Fig. 3 for all
Table 4. Crassostrea gigas and C. angulata. Non-Cut allele frequency (NC freq) after BsrGI digestion, observed $\left(H_{0}\right)$ and expected $\left(H_{\mathrm{e}}\right)$ heterozygosity, and $F_{\text {is }}$ values in each population for the CG44R locus. $F_{\text {is }}(F$-statistic of Wright 1951) was calculated according to Weir \& Cockerham (1984). The significance of the $F_{\text {is }}$ values was estimated by generated permutations $(50000)$ of individual genotypes within each population; ${ }^{*} p<0.05$. Significant values after sequential Bonferroni adjustment at the $\mathrm{p}<0.05$ level are indicated in bold. See Table 1 for population abbreviations

\begin{tabular}{|lccccc|}
\hline Population & $\mathrm{N}$ & $\mathrm{NC}$ freq & $H_{\mathrm{o}}$ & $H_{\mathrm{e}}$ & $F_{\text {is }}$ \\
\hline Oga & 49 & 0.867 & 0.133 & 0.234 & $\mathbf{0 . 4 3 2 *}^{*}$ \\
Seu & 49 & 0.895 & 0.105 & 0.191 & $\mathbf{0 . 4 5 2}^{*}$ \\
Arc & 50 & 0.903 & 0.194 & 0.178 & -0.091 \\
Bou & 49 & 0.907 & 0.140 & 0.171 & $0.184^{*}$ \\
Ori & 50 & 0.984 & 0.032 & 0.032 & 0.000 \\
Rib & 50 & 0.889 & 0.000 & 0.199 & $\mathbf{1 . 0 0 0}^{*}$ \\
Vic & 50 & 0.893 & 0.167 & 0.194 & 0.141 \\
Set1 & 50 & 0.071 & 0.143 & 0.134 & -0.067 \\
Mir & 30 & 0.083 & 0.167 & 0.155 & -0.074 \\
Tar & 50 & 0.217 & 0.304 & 0.344 & 0.116 \\
Rfa & 35 & 0.145 & 0.132 & 0.251 & $\mathbf{0 . 4 7 9}^{*}$ \\
Gua & 50 & 0.122 & 0.204 & 0.217 & 0.061 \\
Cad & 21 & 0.111 & 0.222 & 0.209 & -0.067 \\
Kee & 30 & 0.068 & 0.046 & 0.130 & $\mathbf{0 . 6 5 6}^{*}$ \\
Kao & 40 & 0.125 & 0.250 & 0.222 & -0.130 \\
\hline
\end{tabular}

the populations in the present study. Two geographical groups were distinguished based on the allele frequencies at the COI and CG44R markers. The populations from the French and northern Spanish Atlantic coasts were characterized by high frequencies of C. gigas haplotypes. Its frequency was equal to 1 , except in the Vieux-Boucau and Ribadesella populations where a few $C$. angulata haplotypes were observed ( $f=0.08$ and 0.05 , respectively). In French and north Spanish populations, the CG44R marker showed high frequencies of the NC allele: from 0.89 (Seudre, Ribadesella and Vicedo) to 0.98 (Orio, Table 4). Similarly, the Japanese C. gigas population was fixed for the $C$. gigas haplotypes and showed a high frequency of the NC allele (0.87, Table 4$)$. The second geographic group, composed of southern Spanish and Portuguese populations, was characterized by high frequencies of $C$. angulata haplotypes ( $f=1$ for all populations, except for Ria Formosa: $f=0.89$ ) and high frequencies of the $C$ allele at CG44R (from 0.86 to 0.93 for Ria Formosa and Setubal populations, respectively; Table 4). The Tavira population displayed the highest mix of specific mtDNA haplotypes ( $f=0.18$ and 0.82 for $C$. gigas and $C$. angulata haplotypes, respectively) and CG44R alleles $(f[N C]=0.22$ and $f[C]=0.78)$. Finally, the 2 Taiwanese populations revealed only $C$. angulata haplotypes and high frequencies of the $\mathrm{C}$ allele at the CG44R locus ( $f=0.88$ and 0.93 for Kaohsiung and Tungkang, respectively). 


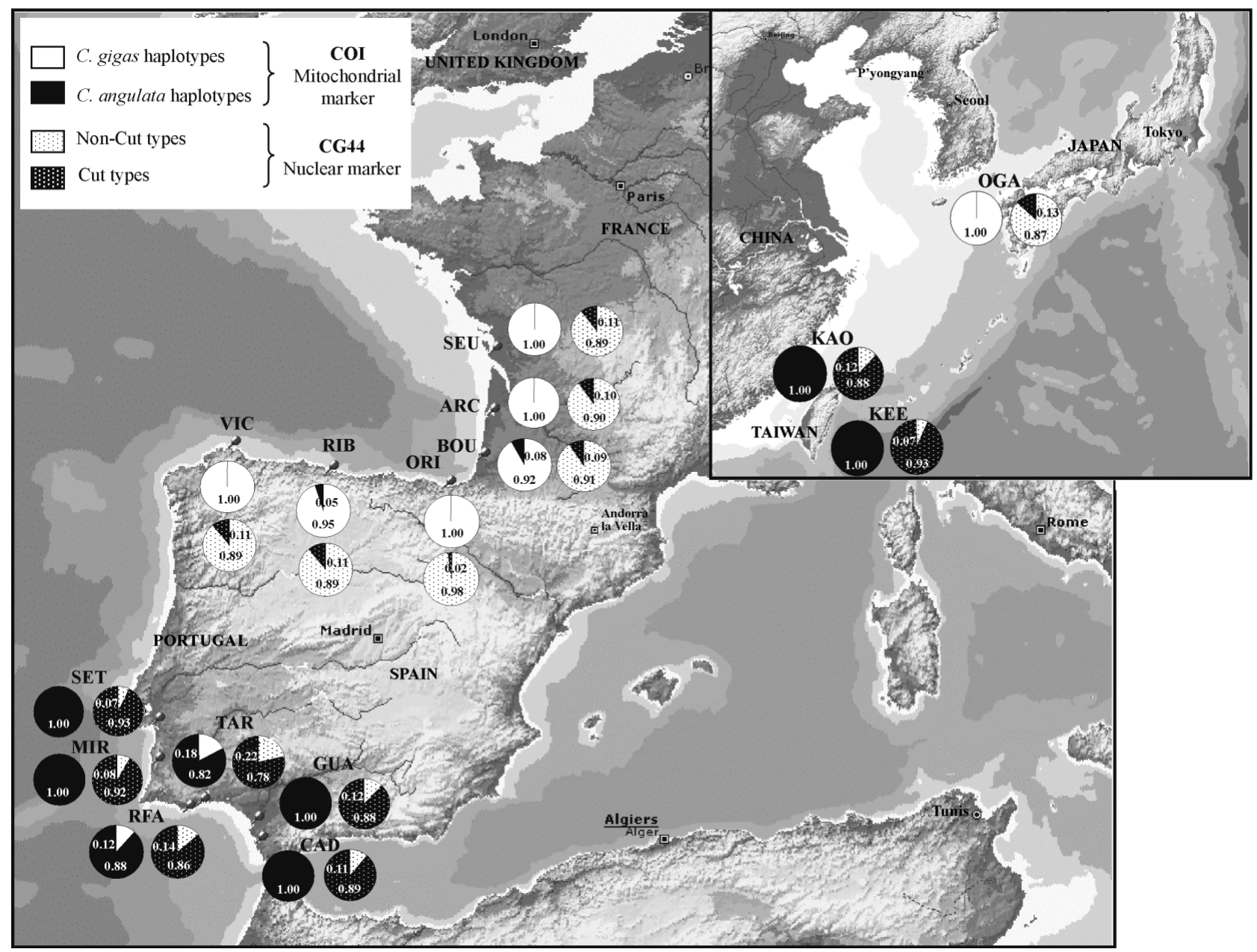

Fig. 3. Crassostrea gigas and C. angulata. Allelic frequencies per population (see Table 1 for population abbreviations)for the 2 PCR-restriction fragment length polymorphism (-RFLP) markers (mitochondrial Cytochrome Oxidase Subunit I [COI] and nuclear CG44R markers). Left or upper pie charts: COI results with 2 taxa-specific haplotype clusters, C. gigas in white and C. angulata in black, grouping all observed haplotypes (according to Boudry et al. 1998 and Huvet et al. 2000b); right or lower pie charts: CG44R results with the NC allele associated with $C$. gigas in white with black dots and the C allele associated with $C$. angulata in black with white dots

\section{DISCUSSION}

\section{Mutation processes at a microsatellite marker and estimation of genetic differentiation between Crassostrea angulata and $C$. gigas}

Because of the high variability of microsatellite loci, they are presently one of the main tools in population genetics, paternity analysis and gene mapping. However, many recent inter- or intra-specific studies have demonstrated the complexity of mutational events occurring in these DNA sequences (Angers \& Bernatchez 1997, Grimaldi \& Crouau-Roy 1997, Steinkellner et al. 1997, Anderson et al. 2000). Inter-specific analyses have often revealed size differences in microsatellite alleles between close species (Deka et al. 1995, Ellegren et al. 1995, Forbes et al. 1995, Rubinsztein et al. 1995a,b, Angers \& Bernatchez 1997). Possible explanations may be: (1) difference in mutation rates between close species (Rubinsztein et al. 1995a,b, Cooper et al. 1998), (2) bias in the screening of microsatellites (Ellegren et al. 1995, 1887, Forbes et al. 1995, Pépin et al. 1995, Watanabe et al. 1996, but see also Cooper et al. 1998) and (3) variations in the $5^{\prime}$ - and 3'-flanking regions (Angers \& Bernatchez 1997, Steinkellner et al. 1997, Anderson et al. 2000). In our results, allele size differences were observed between Crassostrea gigas and C. angulata at some microsatellite loci but not in a unidirectional manner. Screening bias, detected in some previous studies (see Explanation 2, above), does not appear to be the reason for these size differences, because number and size of our microsatellite alleles was not consistently higher in $C$. gigas (the taxon where these microsatellite loci were 
originally screened and isolated) than in C. angulata. Consequently, taxa-specific mutational processes or screening biases are unlikely to provide the reason why size differences were observed between $C$. angulata and C. gigas at some microsatellite markers. Alternatively, the sequence of 2 microsatellite alleles for the locus CG44 showed that mutation rate was not only very high for the number of dinucleotide repeats, but also in the flanking regions where 2 insertions and many point mutations were characterized. It would not be surprising if such mutations occurred in the primer sequences and consequently imply null alleles. Furthermore, incongruence between size and number of mutation events in microsatellite loci (Angers \& Bernatchez 1997) can lead to homoplasy (Grimaldi \& Crouau-Roy 1997). Both phenomena were suggested in a previous microsatellite study of C. angulata and C. gigas populations (Huvet et al. 2000b). Hypotheses of null alleles and homoplasy are therefore supported by the present work, and could explain the significant heterozygote deficiencies observed in C. angulata and C. gigas populations (48\% significant values of $F_{\text {is }}$; Table 3). Among the hypotheses discussed in Huvet et al. (2000b) to explain these heterozygote deficiencies (inbreeding, Walhund effect, selection, null alleles), null alleles appeared to be the best explanation for most of the effect. Null alleles are not detected by PCR because of a mutation in the homologous sequence of the primer (Callen et al. 1993) or an artefact during amplification, such as allelic dropout (heterozygotes for 2 alleles of very different sizes scored as homozygotes for the smaller one due to less efficient amplification of the larger allele). As in our first study (Huvet et al. 2000b), the existence of null alleles is also consistent with the observation of few putative null homozygotes (individuals which showed no amplification at one of the analyzed loci) in the populations showing the strongest heterozygote deficiencies (for example OGA: 3 individuals for CG44 and 2 for L8 and L16 loci). The possibility that natural selection has driven the pattern we observe is unlikely because the results of our test for deviation from selective neutrality indicated that the microsatellites behave in a neutral manner. However, the usatAMY marker showed a significant p-value, suggesting deviation from selective neutrality. This was consistent with the strong reduction in number of alleles (10) and the very high frequency of 1 allele $(f=0.54$ ) observed in the Rio Mira population, compared to those observed in other populations at this marker (mean number of alleles $=20$ and $\left.f_{\max }=0.14\right)$. This marker is located in an intron of the amylase Gene A and its neutrality could be affected by linkage disequilibrium of linked polymorphic exons (see Slatkin 1995b, Sellos et al. 2003). Further studies are needed to determine whether the amylase gene could be under direct selective pressure due to its digestive function and whether the $\mu$ satAMY marker could be useful for breeding programs.

Such complex mutational processes suggest that allele coalescence cannot be easily inferred from size information, and could consequently induce bias in our estimations of genetic differentiation between populations of closely related oyster taxa, as suggested by Angers \& Bernatchez (1997). The genetic differentiation appeared to be 10 times higher between Crassostrea gigas and $C$. angulata populations when estimated using the $R_{\mathrm{st}}$ parameter compared to $F_{\mathrm{st}}$. Whereas $F_{\text {st }}$ estimation is based on allelic identity, $R_{\text {st }}$ estimation is based on allelic size, which theoretically depends on number of mutation events in microsatellite motifs. However, in our data, allele sizes were likely to be strongly affected by insertion/deletion events in flanking regions, and $R_{\text {st }}$ might consequently be overestimated. The presence of null alleles biases the differentiation pattern observed by $F_{\text {st, }}$ but not strongly because its estimation between taxa was no different across all loci, or even without the L16 locus, for which consistent heterozygote deficiencies were observed in all populations.

For the CG44 locus, the $21 \mathrm{bp}$ insertion/deletion fragment was found in most Crassostrea angulata individuals and was absent in most C. gigas. This, together with the exact correspondence of the size of this fragment (21 bp) with the mean allele size difference beween the taxa $(21 \mathrm{bp})$, suggests that this insertion is likely to be the cause of the observed size shift between C. gigas and C. angulata alleles.

\section{Natural hybridization between Crassostrea angulata and $C$. gigas in Europe}

The F-statistic values reported here were considered with caution in the study hybridization between the 2 taxa. Because $F_{\text {st }}$ is a measure of genetic variation among populations relative to the total variation sampled, the within-population variation might therefore be downwardly biased compared to variability between populations. However, in the case of mixed populations without hybridization, $F_{\text {is }}$ values can be greatly enhanced, showing strong heterozygote deficiencies (Wahlund effect). A clear difference in allele frequency was observed between Crassostrea angulata and $C$. gigas populations with the newly designed CG44R nuclear marker, whose polymorphism reveals the presence or absence of the $21 \mathrm{bp}$ insertion. The CG44R alleles are close to being taxon-specific, with allelic frequencies of $0.1 / 0.9$ (NC/C) for pure C. angulata populations and 0.9/0.1 for pure C. gigas populations (taxa previously determined with the mitochon- 
drial marker). This frequency distinction, plus its codominance (i.e. the ability to distinguish heterozygote from homozygote individuals), makes CG44R suitable for searching directly for natural hybridization processes between C. gigas and C. angulata.

Results from CG44R and mtDNA markers displayed 2 geographical zones along the European Atlantic coasts, corresponding to 2 taxonomic clusters. The geographical distribution of the taxa consequently appeared to be simple in Europe: Crassostrea gigas was observed in northern Europe bordered by the headland of northern Spain (La Corogne) in the south, and $C$. angulata was observed in southern Europe. Moreover, we were not able to find any cupped oysters between La Corogne (Spain) and Porto (Portugal), i.e. between the 2 population clusters. Therefore, it can be concluded that no natural contact zone between $C$. angulata and C. gigas exists in Europe, in contrast to those observed in other species of marine invertebrates like mussels (Koehn 1991, Inoue et al. 1997, Bierne et al. 2002, 2003) and clams (Bert et al. 1993). No natural gene flow between European C. angulata and C. gigas populations was shown. Similarly, in the same Spanish region as our study, natural gene flow between algae populations is restricted to within the region due to seawater currents (Alberto et al. 1999). However, natural selective pressure might also play a role, by forcing the allelic repartition we observed here. For example, natural selection between close species of mussels in the Baltic zone was found to explain the discordant patterns of allozyme and non-allozyme loci (Riginos et al. 2002). Selective pressure in the present study could involve the presence or absence of the iridovirus that affected C. angulata populations in the late 1960s and/ or taxa-specific preferential environmental conditions (Haure et al. 2003). However, this second hypothetical selective factor is unlikely to be major, as $C$. angulata was massively present along the French coasts until the late 1960s, where only C. gigas is found today. Concerning the iridovirus, there is limited information about its present distribution in Europe since its last observation in 1984 (Bougrier et al. 1986).

On the basis of the mtDNA marker, a notable mixture of both taxa was observed in 1 population located in the south of Portugal (Tavira). This situation could be the result of the development of oyster farming in this area leading to large-scale importation of Crassostrea gigas spat from France (Arcachon and Marennes Oléron bays) into the south of Portugal. Interestingly, the same mixture pattern was observed with the nuclear CG44R marker. Furthermore, whereas heterozygote deficiencies might be expected in the case of only mixed populations of the 2 taxa, no significant heterozygote deficiencies were observed in this population ( $p=0.116$, Table 4$)$ and the observed het- erozygosity $H_{0}$ was clearly higher than those observed in other populations considered as 'pure'. Although linkage disequilibrium has commonly been observed in hybrid zones (Arnold 1997), no significant linkage disequilibrium was observed in the Tavira population. Indeed, the estimation of nucleo-cytoplasmic linkage disequilibrium revealed a non-significant value in the Tavira population $(\mathrm{d}=0.17, \mathrm{p}=0.102)$ whereas a significant one was observed over all the populations considered together $(d=0.45, p<0.001)$. All these observations lead to the conclusion that natural hybridization occurs in the Tavira population rather than only sympatric distribution of both taxa.

Similarly, Vieux-Boucau and Ribadesella populations were also made up of a mixture of the 2 taxa, though with only a few Crassostrea angulata haplotypes observed among a large number of $C$. gigas haplotypes. This mixture might correspond to an ancestral polymorphism related to the past presence of $C$. angulata in these regions (Grizel \& Héral 1991). However, unlike the Tavira population, allele frequencies at the CG44 locus in these 2 populations did not reveal any significant shift, probably due to the limited level of mixture. In this context, it would be of great interest to further study $C$. gigas and $C$. angulata populations present in Asia (from Japan to southern China) to determine whether these 2 taxa are sympatric and if they hybridize anywhere.

\section{Evolutionary history and past hybridization of the 2 taxa}

The $5.26 \%$ genetic divergence between these 2 Asian taxa, Crassostrea angulata and C. gigas, at the COI gene leads to a rather recent estimate of divergence date at 1 to 2 million yr ago (O'Foighil et al. 1998). Taking into account (1) the large dispersal ability of these taxa; (2) the absence of reproductive barriers between them under experimental conditions (Huvet et al. 2001, 2002); and (3) the low levels of genetic differentiation between populations using allozymes (Mathers et al. 1974, Buroker et al. 1979, Mattiucci \& Villani 1983) and microsatellites (mean $F_{\text {st }}$ between taxa populations $=0.022$ in the present study and in Huvet et al. 2000b), gene flow might exist between these 2 taxa. However, strong genetic differences were observed between the 2 taxa using both the CG44R marker $\left(F_{\text {st }}=0.71\right)$ and the COI mtDNA marker $\left(F_{\text {st }}=0.88\right.$; Huvet et al. 2000b). Because of the higher sensitivity of the mitochondrial genome to drift compared with nuclear DNA (due to its haploid character and maternal transmission; Boursot \& Bonhomme 1986), and because homoplasy might cause underestimation of genetic differentiation at microsatellite markers (Shaw et al. 
1999), one can expect higher estimates of genetic differentiation when using mitochondrial rather than nuclear markers. However, microsatellites are likely to be more resolutive for analysis of the evolutionary history of populations over short temporal and geographical scales (e.g. Angers \& Bernatchez 1998, Hauser et al. 2001). We generally observed higher mitochondrial differentiation compared with nuclear DNA differentiation, except at the CG44R locus. A possible scenario is that, following the initial divergence between the 2 taxa, a secondary contact might have occurred before a second spatial and/or temporal separation. This secondary contact may have allowed limited gene flow resulting in the present frequency distribution of the CG44R alleles. However, the effects of such gene flow on the mitochondrial genome may have been lost because of drift, while the mutation rate of nuclear markers is too fast (microsatellites) or too slow (allozymes) to have enabled it to be traced. This hypothetical gene flow event would have occurred before the introduction of Crassostrea angulata to Europe (since both alleles of CG44R are present over all the populations and their frequencies are similar in European and Asian populations) but recently enough so that allelic frequencies at 'slow' evolving markers remained unchanged. However, alternative hypotheses involving natural selection cannot be rejected, and further information is needed concerning the potential selective pressures (e.g. presence and impact of the iridovirus that affected C. angulata populations). In southern Europe, the recent transplantation of C. gigas for aquacultural purposes (Ruano 1997) has created a contact zone where the 2 taxa hybridize, as shown in the present paper, whereas no natural contact zones were observed along the European coasts. If transplantation of C. gigas to C. angulata areas continues, future studies of this southern European zone would be of great interest to further understand the co-evolution of these taxa.

Acknowledgements. The authors wish to thank A. Gérard and G. Périquet for their support during the course of this work and F. Bonhomme for helpful discussions. The authors are indebted to A. Manjua for her technical assistance. We thank D. Sellos, A. Van Wormhoudt, J. F. Samain and J. Moal for providing primers of the amylase microsatellite and A. Bernoussi, A. Leitao, F. Cornette, P. Goulletquer, T. Huet, F. Lango, D. Tagliapietra, J. H. Cheng, K. Ogawa and F. Rivet for providing oyster samples. We also thank 3 anonymous reviewers for their comments and suggestions on the manuscript. This study was aided financially by the Conseil Général of Charente-Maritime and by an IFREMER contract URM16 to LGPI.

\section{LITERATURE CITED}

Alberto F, Santos R, Leitao JM (1999) Assessing patterns of geographic dispersal of Gelidium sesquipedale (Rhodo- phyta) though RAPD differentiation of populations. Mar Ecol Prog Ser 191:101-108

Anderson TJ, Su XZ, Roddam A, Day KP (2000) Complex mutations in a high proportion of microsatellite loci from the protozoan parasite Plasmodium falciparum. Mol Ecol 9:1599-1608

Angers B, Bernatchez L (1997) Complex evolution of a salmonid microsatellite locus and its consequences in inferring allelic divergence from size information. Mol Biol Evol 14(3):230-238

Angers B, Bernatchez L (1998) Combined use of SMM and non-SMM methods to infer fine structure and evolutionary history of closely related brook charr (Savelinus fontinalus, Salmonidae) populations from microsatellites. Mol Biol Evol 15(2):143-159

Arnold ML (1997) Natural hybridization and evolution. Oxford University Press, New York

Belkhir K, Borsa P, Chikhi L, Raufaste N, Bonhomme F (1996-2001) GENETIX 4.02, logiciel sous Windows TM pour la génétique des populations. Laboratoire Génome, Populations, Interactions, CNRS UMR 5000, Université de Montpellier II

Bert TM, Hesselman DM, Arnold WS, Moore WS, Cruz-Lopez H, Marelli DC (1993) High frequency of gonadal neoplasia in a hard clam (Mercenaria spp.) hybrid zone. Mar Biol 117:97-104

Bierne N, David P, Langlade A, Bonhomme F (2002) Can habitat specialization maintain a mosaic hybrid zone in marine bivalves? Mar Ecol Prog Ser 245:157-170

Bierne N, Borsa P, Daguin C, Jollivet D, Viard F, Bonhomme F, David P (2003) Introgression patterns in the mosaic hybrid zone between Mytilus edulis and M. galloprovinciallis. Mol Ecol 12:447-461

Black WC, Krafsur ES (1985) A Fortran program for the calculation and analysis of two-locus linkage desequilibrium coefficients. Theor Appl Gen 70:491-496

Bohonak AJ (1999) Dispersal, gene flow, and population structure. Q Rev Biol 74:21-45

Boudry P, Heurtebise S, Collet B, Cornette F, Gérard A (1998) Differentiation between populations of the Portuguese oyster, Crassostrea angulata (Lamark) and the Pacific oyster, Crassostrea gigas (Thunberg), revealed by mtDNA RFLP analysis. J Exp Mar Biol Ecol 226:279-291

Boudry $\mathrm{P}$, Heurtebise S, Lapègue S (2003) Mitochondrial and nuclear DNA sequence variation of presumed Crassostrea gigas and $C$. angulata specimens: a new oyster species in Hong Kong? Aquaculture 228:15-25

Bougrier S, Raguenes G, Bachere E, Tige G, Grizel H (1986) Essai de réimplantation de Crassostrea angulata en France, résistance au chambrage et comportement des hybrides C. angulata-C. gigas. ICES, Copenhagen

Boursot P, Bonhomme F (1986) Génétique et évolution du génome mitochondrial des métazoaires. Gen Select Evol 18:73-98

Buroker NE, Hershberger WK, Chew KK (1979) Population genetics of the family Ostreidae. I. Intraspecific studies of Crassostrea gigas and Saccostrea commercialis. Mar Biol 54:157-169

Callen FD, Thompson AD, Shen Y, Phillips HA, Richards RI, Mulley JC, Sutherland GR (1993) Incidence and origin of 'null' alleles in the (AC)n microsatellite markers. Am J Gen 52:922-927

Chakraborty R (1990) Mitochondrial DNA polymorphism reveals hidden heterogeneity within some Asian populations. Am J Hum Gen 47:87-94

Comps M (1969) Observations relatives à l'infection branchiale des huîtres portugaises (Crassostrea angulata 
Lmk). Rev Inst Pêch Mar 33:151-160

Cooper G, Rubinsztein DC, Amos W (1998) Ascertainment bias cannot entirely account for human microsatellites being longer than their chimpanzee homologues. Hum Mol Gen 7:1425-1429

Deka R, Jin L, Shriver MD, Yu LM and 5 others (1995) Population genetics of dinucleotide (dC-dA)n (dG-dT)n polymorphisms in world populations. Am J Hum Gen 56: 461-474

Ellegren H, Primmer CR, Sheldon BC (1995) Microsatellite 'evolution': directionality or bias? Nat Gen 11:360-362

Ellegren H, Moore S, Robinson N, Byrne K, Ward W, Sheldon BC (1997) Microsatellite evolution-a reciprocal study of repeat lengths at homologous loci in cattle and sheep. Mol Biol Evol 14:854-860

Forbes SH, Hogg JT, Buchanan FC, Crawford AM, Allendorf FW (1995) Microsatellite evolution in congeneric mammals: domestic and bighorn sheep. Mol Biol Evol 12:1106-1113

Gaffney PM, Allen SK (1993) Hybridization among Crassostrea species: a review. Aquaculture 116:1-13

Goodman SJ (1997) R $\mathrm{R}_{\mathrm{ST}}$ Calc: a collection of computer programs for calculating estimates of genetic differentiation from microsatellite data and determining their significance. Mol Ecol 6:881-885

Goulletquer P, Wolowicz M, Latala A, Geairon P, Huvet A, Boudry P (1999) Comparative analysis of oxygen consumption rates between cupped oyster spat of Crassostrea gigas of French, Spanish and Taiwanese origins. Aquat Living Res 12:271-277

Grimaldi MC, Crouau-Roy B (1997) Microsatellite allelic homoplasy due to variable flanking sequences. J Mol Evol 44:336-340

Grizel H, Héral M (1991) Introduction into France of the Japanese oyster (Crassostrea gigas). J Cons Int Explor Mer 47:399-403

Haure J, Huvet A, Palvadeau H, Nourry M, Pénisson C, Martin JLY, Boudry P (2003) Feeding and respiratory time activities in the cupped oysters Crassostrea gigas, Crassostrea angulata and their hybrids. Aquaculture 218: $539-551$

Hauser L, Turan C, Carvalho GR (2001). Haplotype frequency distribution and discrimatory power of two mtDNA fragments in a marine pelagic teleost (Atlantic herring, Clupea harengus). Heredity 87:621-630

Hedgecock D (1986) Is gene flow from pelagic larval dispersal important in the adaptation and evolution of marine invertebrates? Bull Mar Sci 39:550-564

Hedgecock D (1994) Population genetics of marine organisms. US Globec News 6:1-15

Hedgecock D, Li G, Banks MA, Kain Z (1999) Occurrence of the Kumamoto oyster Crassostrea sikamea in the Ariake Sea, Japan. Mar Biol 133:65-68

Héral M (1986) L'ostréiculture française traditionnelle. In: Barnabé G (ed) Aquaculture, Vol 1. Tech \& Doc, Lavoisier, Paris, p 345-390

His E (1972) Premiers éléments de comparaison entre l'huître portugaise et l'huître japonaise. Sci Pêche Bull Inst Pech Mar 219:1-9

Huvet A, Boudry P, Ohresser M, Delsert C, Bonhomme F (2000a) Variable microsatellites in the Pacific cupped oyster Crassostrea gigas and other cupped oyster species. Anim Gen 37:71-72

Huvet A, Lapègue S, Magoulas A, Boudry B (2000b) Mitochondrial and nuclear DNA phylogeography of Crassostrea angulata, the Portuguese oyster endangered in Europe. Conserv Gen 1:251-262

Huvet A, Balabaud K, Bierne N, Boudry P (2001) Microsatel- lite analysis of 6-hour-old embryos reveals no preferential intra-specific fertilization between cupped oysters Crassostrea gigas and Crassostrea angulata. Mar Biotechnol 3: $448-453$

Huvet A, Gérard A, Ledu C, Phélipot P, Heurtebise S, Boudry $P$ (2002) Is fertility of hybrids enough to conclude that the 2 oysters Crassostrea gigas and Crassostrea angulata are the same species? Aquat Living Resour 15:45-52

Inoue $\mathrm{K}$, Odo $\mathrm{T}$, Noda $\mathrm{S}$, Nakao S, Takeyama E, Yamaha B, Yamazaki F, Harayama S (1997) A possible hybrid zone in the Mytilus edulis complex in Japan revealed by PCR markers. Mar Biol 128:91-95

Koehn RK (1991) The genetics and taxonomy of species in the genus Mytilus. Aquaculture 94:125-145

Leitão A, Boudry P, Labat JP, Thiriot-Quiévreux C (1999a) Comparative karyological study of cupped oyster species. Malacologia 41:175-186

Leitão A, Thiriot-Quiévreux C, Boudry P, Malheiro I (1999b) A ' $\mathrm{G}$ ' chromosome banding study of three cupped oyster species: Crassostrea gigas, Crassostrea angulata and Crassostrea virginica (Mollusca: Bivalvia). Gen Select Evol 31:519-527

Magoulas A, Gjetvaj B, Terzoglou V, Zouros E (1998) Three polymorphic microsatellites in the Japanese oyster, Crassostrea gigas (Thunberg). Anim Gen 29:63-72

Mathers NF, Wilkins NP, Walne PR (1974) Phosphoglucose isomerase and esterase phenotypes in Crassostrea angulata and C. gigas. Biochem Syst Ecol 2:93-96

Mattiucci S, Villani F (1983) Studio elettroforetico dei sistemi gene-enzima in ostriche classificate come Crassostrea gigas (Thunberg, 1793) e Crassostrea angulata (Lamarck, 1819) (Mollusca: Ostreidae). Parasitologia 25:21-27

Moore D (1993) Preparation of genomic DNA from mammalian tissue. In: Ausubel FM (ed) Current protocols in molecular biology, Vol 1, Unit 2-2. John Wiley \& Sons, New York, p 1-2

O'Foighil D, Gaffney PM, Wilbur AE, Hilbish TJ (1998) Mitochondrial cytochrome oxidase I gene sequences support an Asian origin for the Portuguese oyster Crassostrea angulata. Mar Biol 131:497-503

Palumbi SR, Wilson AC (1990) Mitochondrial DNA diversity in the sea urchins Strongylocentrotus purpuratus and $S$. droebachiensis. Evolution 44:403-415

Parache A (1989) Growth performance of oyster Crassostrea angulata and Crassostrea gigas reared in Arcachon Bay between 1950 and 1986: first results. Haliotis 19:227-236

Pépin L, Amigues Y, Lepingle A, Berthier JL, Bensaid A, Vaiman D (1995) Sequence conservation of microsatellites between Bos taurus (cattle), Capra hircus (goat) and related species. Examples of use in parentage testing and phylogeny analysis. Heredity 74:53-61

Ranson G (1948) Ecologie et répartition géographique des Ostréidés vivants. Rev Sci 86:469-473

Rawson PD, Agrawal V, Hilbish TJ (1999) Hybridization between the blue mussels Mytilus galloprovincialis and M. trossulus along the Pacific coast of North America: evidence for limited introgression. Mar Biol 134:201-211

Rice WR (1989) Analyzing tables of statistical tests. Evolution 43:223-225

Riginos C, Sukhdeo K, Cunningham CW (2002) Evidence for selection at multiple loci across a mussel hybrid zone. Mol Biol Evol 19:347-351

Ruano F (1997) Fisheries and farming of important marine bivalves in Portugal. In: Mackenzie CL Jr et al. (ed) The history, present condition and future of the molluscan fisheries of North and Central America and Europe, Vol 3, Europe. NOAA Technical Report NMFS 129, US Depart- 
ment of Commerce, Seatlle, p 191-200

Rubinsztein DC, Amos W, Leggo J, Goodburn S, Jain S, Li SH et al. (1995a) Microsatellite evolution-evidence for directionality and variation in rate between species. Nat Gen 10:337-343

Rubinsztein DC, Leggo J, Amos W (1995b) Microsatellites evolve more rapidly in humans than in chimpanzees. Genomics 30:610-612

Schneider S, Roessli D, Excoffier L (2000) Arlequin Ver. 2.000: a software for population genetics data analysis. Genetics and Biometry Laboratory, University of Geneva

Sellos D, Moal J, Degremont L, Huvet A and 5 others (2003) Structure of amylase genes in populations of Pacific cupped oyster (Crassostrea gigas): tissue expression and allelic polymorphism. Mar Biotechnol 5:360-372

Shaw PW, Pierce GJ, Boyle PR (1999) Subtle population structuring within a highly vagile marine invertebrate, the veined squid Loligo forbesi, demonstrated with microsatellite DNA markers. Mol Ecol 8:407-417

Slatkin M (1995a) A measure of population subdivision based on microsatellite allele frequencies. Genetics 139:457-462

Slatkin M (1995b) Hitchhiking and associative overdomi-

Editorial responsibility: Otto Kinne (Editor),

Oldendorf/Luhe, Germany nance at a microsatellite locus. Mol Biol Evol 12:473-480

Soletchnik P, Huvet A, Le Moine O, Razet D, Geairon P, Faury N, Goulletquer P, Boudry P (2002) A comparative field study of growth, survival and reproduction of Crassostrea gigas, C. angulata and their hybrids. Aquat Living Resour 15:243-250

Steinkellner H, Lexer C, Turetschek E, Glössl J (1997) Conservation of (GA) $n$ microsatellite loci between Quercus species. Mol Ecol 6:1189-1194

Taylor MS, Hellberg ME (2003) Genetic evidence for local retention of pelagic larvae in a Caribbean reef fish. Science 299:107-109

Watanabe Y, Sakazume T, Kurosaki K, Oota H, WashioWatanabe K, Ueda S (1996) Short tandem repeat polymorphisms in Japanese macaques; their short repeat lengths and low informativeness. Mamm Genome 7:383-385

Weir BS, Cockerham CC (1984) Estimating F-statistics for the analysis of population structure. Evolution 38:1358-1370

Wilkinson L (1990) SYSTAT: the system for statistics. SYSTAT, Evanston

Wright S (1951) The genetical structure of populations. Ann Eugen 15:323-354

Submitted: June 10, 2003; Accepted: February 17, 2004 Proofs received from author(s): April 28, 2004 